\title{
Macroalgas Marinhas - um campo de investigação sempre novo
}

Numa curta definição botânica [1] pode dizer-se que algas são plantas simples, principalmente aquáticas, que possuem clorofila, com corpo não diferenciado em raízes, talos ou folhas verdadeiras, carecendo de sistema vascular e reproduzindo-se mediante esporos. As algas macroscópicas estão agrupadas em três grandes divisões: clorofíceas (algas verdes), feofíceas (algas castanhas) em que a clorofila se encontra mascarada por um pigmento laranja, a fucoxantina, e rodofíceas (algas vermelhas) em que a clorofila está mascarada por um pigmento vermelho, a ficoeritrina. Membros destas três classes encontram-se representados na costa portuguesa [2].

As macroalgas marinhas, tal como outros recursos naturais, têm sido utilizadas pelo Homem. A utilização mais simples e que requer menos conhecimentos técnicos é como adubo. As espécies usadas são algas castanhas de grandes dimensōes (laminárias) ou verdes, como a Ulva lactuca, vulgarmente conhecida por alface do mar, muito ricas em azoto e potássio e pobres em fósforo. Porém o uso prolongado obriga à adição suplementar de fosfatos. Pelo seu alto conteúdo em potássio, são especialmente indicadas em culturas de hortaliças como a cenoura, o nabo e praticamente todo o tipo de couve. Comparando com a adubação tradicional com estrume, a utilização de algas apresenta a vantagem de estas se encontrarem livres de sementes e fungos.

Alguns autores [3] pensam que o valor como adubo das macroalgas marinhas é devido à presença de hormonas de crescimento das plantas. De facto, foram identificados, em várias espécies de algas castanhas (como Ascophyllum e Fucus) os ácidos indol-acético e giberélico que favorecem o crescimento e divisão celular em plantas superiores e aceleram a germinação das sementes.
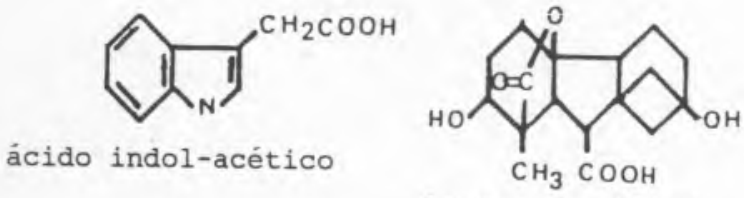

ácido giberélico

A medicina popular também tem utilizado várias algas com fins curativos [4]. Do Condrus crispus, conhecido por alga perlada ou musgo-da-Irlanda, faz-se uma geleia com água fervente aconselhada para o tratamento da diarreia. Um banho com uma decocção desta alga, ou de laminárias completamente secas, é recomendado para casos de raquitismo. O banho com decocção de bodelha, nome por que é conhecido o Fucus vesiculosos, é aconselhado para emagrecer.
É também indicada a fricção com bodelha fresca como remédio contra a celulite. Outra alga cuja utilização já vem da Idade Média é o musgo-da-Córsega, designação popular do Alsidium helminthocorton, pequena alga vermelha muito rica em iodo, que é um óptimo estimulante da tiróide e um vermífugo potente. Segundo a tradição, era frequentemente utilizado por Napoleão.

\section{INTERESSE INDUSTRIAL DAS MACROALGAS MARINHAS}

\section{Como fonte de elementos}

A utilização das algas tem variado ao longo dos tempos, de acordo com as condições económicas da altura. Nos séculos XVII e XVIII, houve uma grande recolha das espécies Laminária e Fucus para produção de soda a partir das cinzas. Com a descoberta, em 1811, da presença de iodo nestas cinzas e sua aplicação em Medicina, a recolha de algas para a produção industrial de iodo sofreu um grande incremento, tendo-se mantido uma indústria florescente até aos anos trinta do século actual. As algas mais utilizadas pertenciam às espécies Laminária, Ecklonia e Sargassum. De facto, embora a quantidade de iodo na água do mar seja de 0,01 a 0,07 ppm, uma alga da família das fucóides, como o Ascophyllum, pode concentrá-lo mais de 220 vezes. Nos E.U.A., para além da recolha para a produção de iodo, foram utilizadas as grandes algas castanhas da costa do Pacífico - Macrocystis e Nereocystis - como matéria-prima para a produção de potassa em virtude do seu elevado teor em potássio: 15,5 e $19,6 \%$, respectivamente.

\section{$\mathrm{Na}$ alimentação humana}

Várias espécies de Porphyra, alga vermelho-escuro formada por várias "folhas"' semitransparentes e que cresce na zona de maré, são cultivadas no Japão para a preparação do Nori, que é comercializado na forma de finas folhas roxo-escuro. Depois de cozido ou grelhado muda de cor para verde e é introduzido em sopas, molhos ou enrolado com carne, como uma sande. O valor nutritivo do Nori é devido ao elevado conteúdo em proteínas (25-35\%), vitaminas, sais minerais e, especialmente, iodo. $\mathrm{O}$ conteúdo em vitamina $\mathrm{C}$ é uma vez e meia o das laranjas. Os seres humanos digerem cerca de $75 \%$ das proteínas e dos glúcidos da respectiva composição.

\footnotetext{
a CECUL - Departamento de Quimica da Faculdade de Ciências de Lisboa, Instituto Bento da Rocha Cabral, Calçada Bento da Rocha Cabral, 14, 1200 Lisboa.
} 


\section{Como fonte de carregenina}

As algas vermelhas Condrus crispus e Gigartina stellata, espécies muito abundantes na costa irlandesa e que se encontram ao longo da costa atlântica até Portugal, são produtoras de uma mucilagem - a carragenina - com importantes propriedades gelificantes.

As carrageninas são formadas por polissacáridos com unidades de galactose sulfatada, sendo as unidades principais conhecidas por $\lambda-\mathrm{e} \mathrm{k}-$ carragenina.
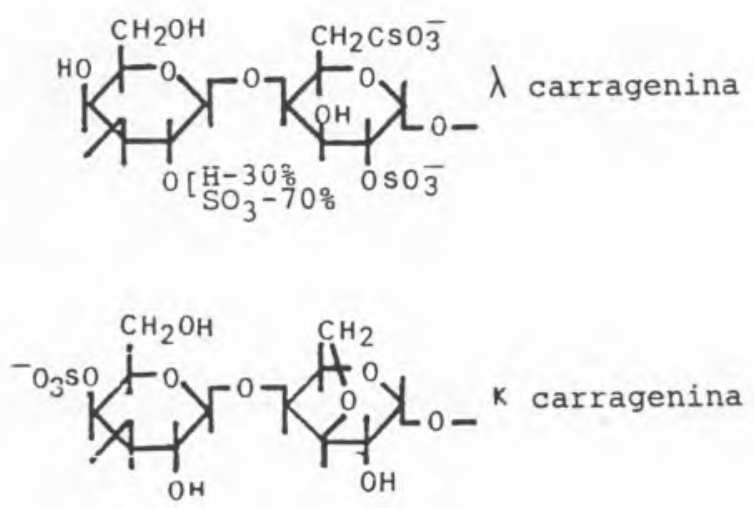

Tem utilizações muito diversas: usa-se em pastas dentríficas, loções para as mãos, cremes de barbear, xaropes para a tosse (como emulsionante do princípio activo), leites achocolatados (provoca uma melhor dispersão do chocolate no leite), pudins instantâneos, gelados, queijos de pasta mole, etc... E também utilizada na indústria têxtil, para obtenção de uma melhor estampagem dos tecidos, e na indústria dos curtumes para amaciar e dar brilho ao cabedal.

A carragenina faz ainda parte de géis para perfumar o ambiente: $\mathrm{o}$ aroma é libertado pela secagem gradual do gel.

\section{Como fonte de agar-agar}

O agar-agar é outra substância com a propriedade de formar géis. A designação agar é de origem malaia e é o nome da alga vermelha da qual ele era extraído. É constituído por dois polissacáridos: agorose a agaropectina. A primeira é responsável pelas propriedades gelificantes enquanto a viscosidade depende da segunda. Estudos efectuados para determinar a estrutura da agarose [3] mostram que esta é formada por unidades de D-galactose ligadas entre si pelas posições 1-3 e por unidades de 3,6-anidro-L-galactose ligadas pelas posições 1-4.

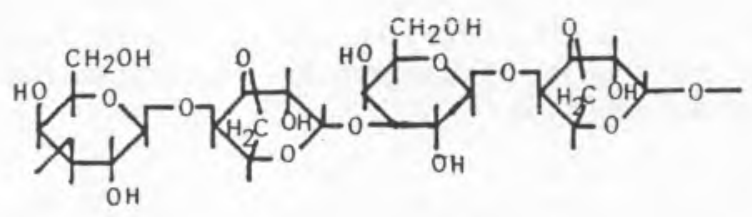

Conforme a proveniência (o agar pode ser extraído de diferentes algas vermelhas) a proporção de agarose e agaropectina varia. Em Portugal, a principal alga colhida para a obtenção de agar é o Gelidium sesquipedale.

Em traços gerais, a produção de agar-agar processa-se do seguinte modo: depois da colheita, a alga é escolhida e posta de molho durante 12 a 14 horas, após o que é transferida para uns autoclaves especiais e "cozida" durante 6 horas, sendo o processo repetido 3 vezes. A solução obtida é descorada com carvão activado, filtrada e colocada em tanques abertos, durante 24 horas, para tomar a consistência de geleia. O gel formado é cortado em fatias e levado para uma câmara onde é arrefecido a $-10^{\circ}$ durante dois dias. Em seguida é removido, deixado descongelar e colocado num dispositivo que permite que a água escorra e arraste as impurezas solúveis. É seco com uma corrente de ar quente até conter apenas $35 \%$ de humidade e branqueado com hipoclorito de sódio a $1 \%$. O hipoclorito é reduzido com sulfito de sódio e o agar-agar é recolhido, lavado e deixado secar até conter apenas $20 \%$ de humidade.

Uma das utilizações mais importantes do agar é em trabalhos de bacteriologia ou cultura de fungos pois, após adicionados os nutrientes necessários, forma um óptimo meio no qual bactérias e fungos podem crescer. A indústria farmacêutica utiliza-o como excipiente em comprimidos e supositórios e, só ou associado a outros compostos, como um lubrificante valioso em casos de obstipação.

$\mathrm{Na}$ indústria alimentar, é utilizado como espessante de sopas e molhos, de leites com aromas, de geleias, doces e bolos. É utilizado nos gelados para impedir que a água congele em cristais e se separe dos restantes constituintes. É ainda usado no fabrico de geleias de frutos, substituindo com vantagens a gelatina devido ao seu baixo custo e rapidez de solidificação. O agar não é praticamente digerido, pelo que não modifica o valor nutritivo dos alimentos.

\section{Como fonte de alginatos}

O ácido algínico é um polissacárido complexo, formado por unidades dos ácidos D-manurónico e L-gulurónico, ligados pelas posições 1-4. O arranjo dos vários monómeros e a massa molecular varia conforme a alga donde é extraído. Existe sobretudo nas algas castanhas, tanto nas grandes laminárias como nos pequenos fucus. $\mathrm{O}$ modo mais simples de o obter é macerar a alga com ácido clorídrico diluído para remover os sais minerais solúveis, seguindo-se uma extracção com uma solução de carbonato de sódio. O líquido resultante, bastante viscoso, é tratado com mais ácido. O precipitado formado é filtrado e lavado, obtendo-se então o ácido algínico.

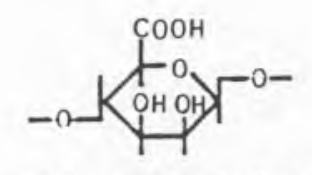

ácido D-manurónico

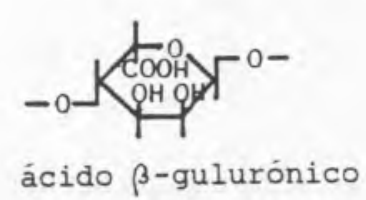

A utilização do ácido algínico ou do respeçtivo sal sódico estende-se a vários campos:

- na indústria têxtil, para dar brilho às fibras e como espessante dos corantes utilizados no tingimento dos tecidos; 
- na indústria farmacêutica, para promover a suspensão de alguns princípios activos, nomeadamente a penicilina; - na indústria das tintas, para melhorar a suspensão dos pigmentos e a estabilização das emulsões;

- e na indústria alimentar, onde é largamente utilizado como estabilizante de batidos ou sumos de fruta, para evitar a formação de cristais de gelo nos gelados e para dar uma melhor textura aos pudins instantâneos.

\section{NOVAS PERSPECTIVAS NO CAMPO FARMACOLÓGICO}

O campo de aplicação dos produtos extraídos das algas não se restringe aos atrás enumerados. Actualmente, a flora e a fauna marinhas são encaradas como uma fonte altamente prometedora de substâncias com actividade farmacológica. Num estudo efectuado na Faculdade de Farmácia de Nantes [5], foram investigadas 91 espécies de algas bênticas da costa atlântica francesa, tendo seis delas apresentado actividade bactericida e quatro outras actividade antifúngica. Os compostos isolados apresentam estrutura muito diversa, desde um álcool cetónico diterpénico, como a eleganolona, extraída da Bifurcaria bifurcata e Cystoseira elegans, a lactonas, como os fimbrolidos da Delisia fimbriata ou, ainda, a compostos halogenados, como as poli-halopropanonas, extraídas da Bonnemaisonia sp.

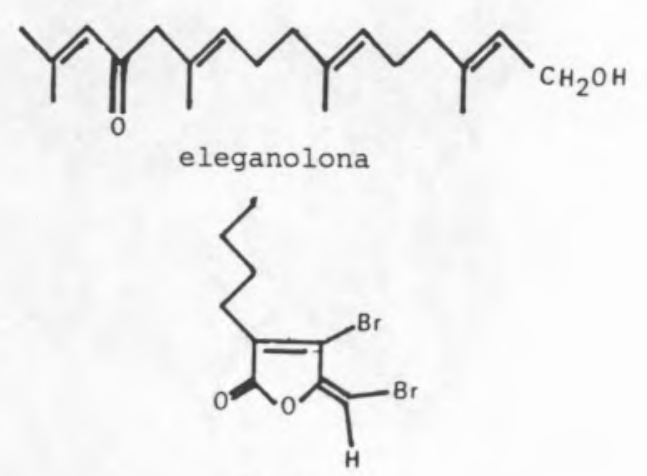

fimbrolido<smiles>O=C(CBr)CBr</smiles>

poli-halopropanona

Um outro estudo, efectuado sobre 31 espécies da costa mediterrânica [6], assinala onze espécies biologicamente activas: três bactericitas, três antifúngicas e cinco com as duas propriedades. Infelizmente, este estudo foi efectuado com os extractos brutos, pelo que não foram isolados os princípios activos.

O potencial interesse do estudo das algas está bem patente no esforço desenvolvido pela multinacional Hoffman-La Roche, que financiou um instituto de investigação marinha na Austrália, o Roche Research Institute of Marine Pharmacology, durante sete anos (1974-81) [7]. Nesse período, foram colhidas e testadas do ponto de vista farmacológico (anti-tumural, bacteticida, fungicida, anti-alérgico, analgé- sico, cardiovascular, etc.) 159 espécies de algas da costa australiana, tanto macroalgas como microalgas, tendo sido vários os compostos isolados. Como curiosidade, refere-se um composto activo em casos de hiper-reflexia e que foi isolado da alga vermelha Plocamium cartilageneum.<smiles>C=C1C[C@](C)(Cl)[C@H](Br)C[C@H]1/C=C/Cl</smiles>

Esta alga é também muito abundante na costa portuguesa, onde aparece como epífito do Gelidium sesquipedale.

Para além do interesse no aproveitamento industrial dos compostos extraídos de macroalgas marinhas, outros aspectos há que constituem um permanente desafio ao químico orgânico, tanto na elucidação de estruturas como na síntese desses compostos. Os exemplos a seguir apresentados recolhidos ao acaso da literatura especializada [8-10], ilustram bem as dificuldades que o estudo dos Produtos Naturais marinhos encerram.
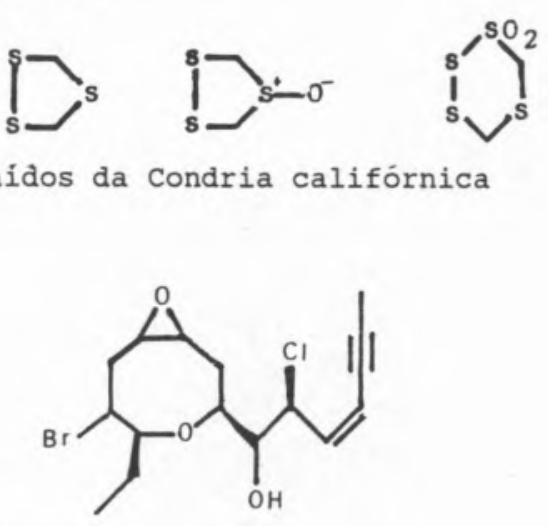

extráido da Laurência potei

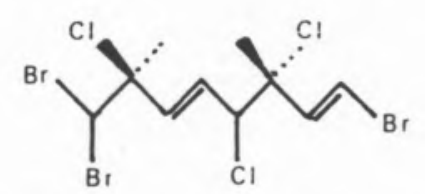

extraído do Plocamium cartilageneum

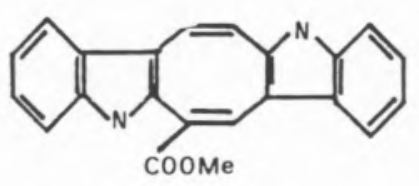

extraído da Caulerpa sp

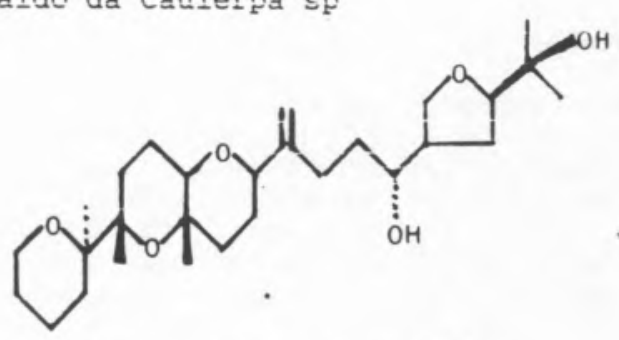

extraído da Laurência pinatifida

(muito abundante na costa portuguesa) 


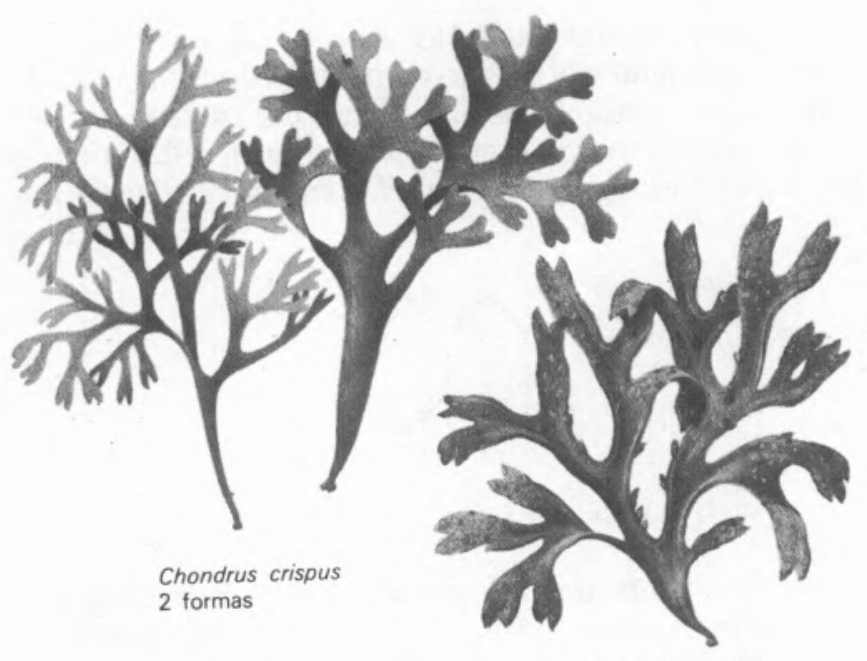

Gigartina stellata

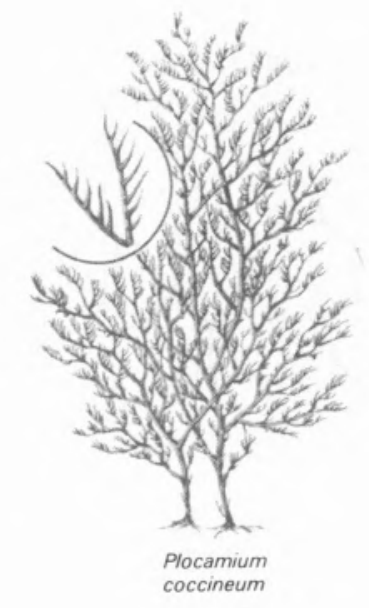

\section{Referências}

[1] A.C. Campbell - " "Guia de campo de la Flora y Fauna de las Costas de España y de Europa", Ed. Omega, S.A., Barcelona, 1979

[2] F. Ardré - "Contribution à l'Étude des Algues marines du Portugal: I La Flore", Port. Acta Biol. (B), 1970, 10, 137-352

[3] V. J. Chapman e D. J. Chapman-"Seaweeds and their uses", Chapman and Hall, 3 a ed., New York, 1980

[4] "Segredos e Virtudes das Plantas Medicinais", Selecções do Reader's Digest, Lisboa, 1983

[5] J. F. Biard - " Recherche et Étude de Substances Antimicrobiennes et Antineoplasiques dans les Algues Benthiques des Côtes Atlantiques Françaises", Thèse pour le Doctorat d'État en Sciences
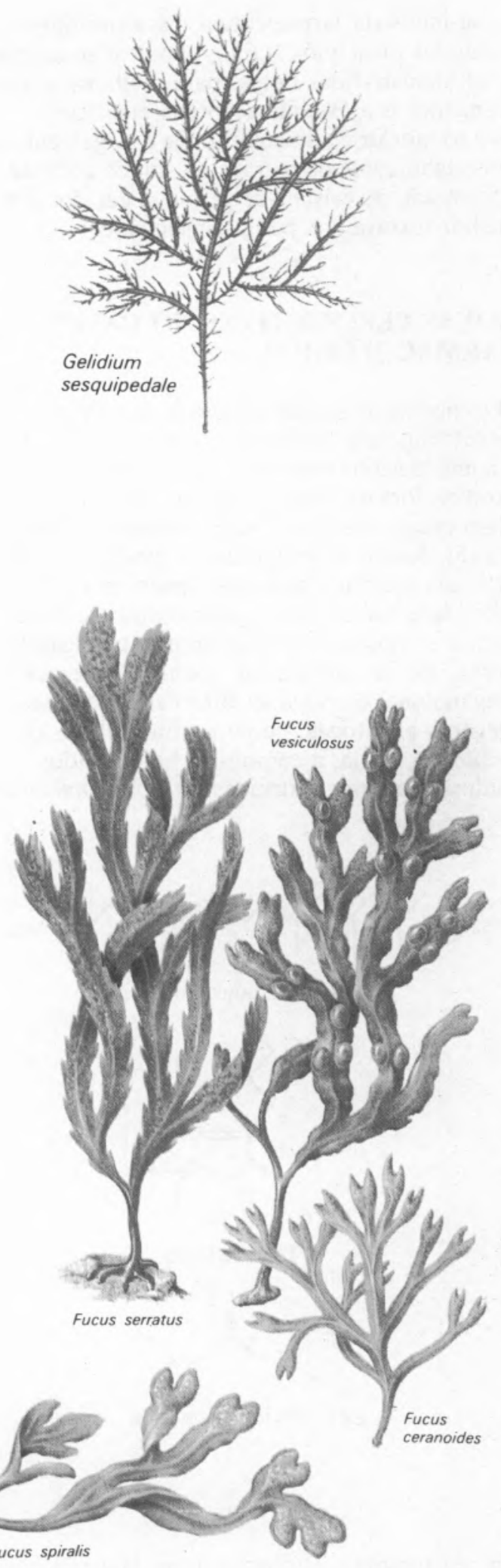

Pharmaceutiques, Universidade de Nantes, 1980

[6] D. Pesando e B. Caram - "Screening of Marine Algae from the French Mediterranean Cost for Antibacterial and Antifungal Activity", Botanica Marina, 1984, 27, 381-86

[7] J. T. Baker - "'Seaweeds in Pharmaceutical Studies and Applications", Hydrobiologica, 1984, 116-17, 29-30

[8] D. J. Faulkner - "Interesting Aspects of Marine Natural Product Chemistry", Tetrahedron, 1977, 33, 1421-43

[9] D. J. Faulkner - "Marine Natural Products: Metabolites of Marine Algae and Herbivorous Marine Molluscs", Natural Product Reports, $1984,1,251-80$

[10] D. J. Faulkner - "Marine Natural Products", Natural Product Reports, 1986, 3, 1-33 